\title{
Teacher Education Institutions in the Philippines towards Education 4.0
}

\author{
Rivika Alda, Helen Boholano and Filomena Dayagbil \\ Cebu Normal University, Cebu City, Cebu Philippines \\ https://orcid.org/0000-0002-1546-9042 \\ https://orcid.org/0000-0003-4365-3370 \\ https://orcid.org/0000-0002-3373-9931
}

\begin{abstract}
Education must reflect the world it is training students for. Education 4.0 ensures that teaching-learning experiences will take advantage of the limitless opportunities created by advanced technology. This study determines the readiness of teacher education institutions in the Philippines for Education 4.0 in the areas of faculty, teaching and learning, infrastructure, and research as perceived by the administrators and faculty members of teacher education institutions in the Philippines. This study made use of survey questionnaire indicating the four parameters mentioned, and data were analysed using quantitative method. The findings of this study suggest that administrators and faculty members perceived that they are ready in terms of their skills in selecting and integrating digital resources for teaching and learning as they are also given capacity buildings through seminars and conferences related to technological literacy. However, they are neither skillful in using the learning management system and other online class modality; nor in the utilization of augmented reality, robotics, and digital enablers like 3D printing. This finding may be attributed to the unavailability and inaccessibility of digital infrastructure and virtual laboratories in most teacher education institutions. The respondents also disagreed that the teacher education institutions are ready in terms of research programs and initiatives for Education 4.0. Thus, there is a need for teacher education institutions to rethink infrastructure planning, redesign research initiatives, and strengthen teacher-training capabilities to be Education 4.0 ready.
\end{abstract}

Keywords: Industry 4.0; Education 4.0; Teacher education institutions; Teacher readiness; Teaching and learning

\section{Introduction}

The fourth Industrial Revolution "blurs the lines among the physical, digital, and biological worlds" (Shahroom \& Hussin, 2018, p. 316). It transforms the world through its impressive progress in creating technological breakthroughs and 
limitless possibilities. These technological advancements have dominated the lives and lifestyles of people.

Schwab (2016), purports that these great shifts brought about by the Fourth Industrial Revolution (4 $\left.4^{\text {th }} \mathrm{IR}\right)$ in human history offer either considerable promise or potential peril. The Global statistics in Whelsh (2018) reveal that in the fourth industrial revolution, $65 \%$ of the students in grade school will later on work in jobs that are yet to be invented. At least $49 \%$ of the existing posts can be replaced by machines as most activities are already automated. Machines will also outperform at least $80 \%$ of the skills people are trained in the last 50 years. While others may see that the future of the internet provides balance and equal access to almost everything, others warn that it may also be used for control and exploitation. "In the new manufacturing regime enabled by 4IR technologies, sometimes called the Internet of Things (IoT), nearly anything can be designed on a computer and then printed on 3D printers that create objects in countless materials or even biological tissues" (Penprase, 2018, p. 217).

Industry 4.0 has posed a significant challenge to the educational landscape in the Philippines and worldwide. According to World Economic Forum Asian Development Bank (2017, p.7) that 4IR "is building on the digital technologies of the $3^{\text {rd }} \mathrm{IR}$, and powered by a wide range of breakthroughs in the digital realm (such as artificial intelligence), physical realm (new materials), as well as the biological realm (bio-engineering)". With the shift in the world of learning brought about by the 4th IR, Education 4.0 - a model of education for the future emerges, affording educators potentially far-reaching challenges (Fisk, 2017). It is an era of creating innovative knowledge that becomes obsolete the next day, and new knowledge emerges (Puncreobutr, 2016). Pangandaman et al. (2019) purport that Industry 4.0 necessitates that the educational system supports a globalized learning environment and experiences that are "automatized, networked, virtualized, and flexible." Schools should prepare students for the future of work. Students should be capable and ethical in the utilization of these new technological tools. They should also be critical, creative, self-directed, reflective, and decent citizens and leaders. This scenario calls for higher learning institutions to keep abreast of these latest trends and come up with new and responsive ways to enhance teaching and learning.

Data from Future of Jobs Reports, World Economic Forum (2016) in Haron (2018, p. 12) highlighted the top essential skills for 2020. These are "complex problem solving, critical thinking, creativity, management, coordinating with others, emotional intelligence, judgment and decision-making, service orientation, negotiation, and cognitive flexibility". With this, schools should also be able to connect education and employment, improve forecasts by establishing linkages to industry and labor-market trends, and re-examine education and labor policy for them to stay driven and relevant to the everchanging market realities (Lodder, 2016 in Haron, 2018). In the same context, Xing and Marwala (2017) had laid down the framework for Teaching in IR 4.0, which will be the focus of Education 4.0. They are the following: "teaching (wearables assisted teaching-learning-andtraining, embrace massive open online courses, cultivating innovative talent, 
generalize blended learning); research (open innovation, evolutionary \& revolutionary innovations, new technological advancement, driven research and development, shorten innovation cycles); and service (University-as-a-Platform (UaaP), Education-as-a-Service (EaaS), Internationally-linked Programs)."

Moreover, Fisk (2017) also presented the following trends related to Education 4.0. First, learning is ubiquitous; thus e-learning tools and flipped classroom approach provides greater opportunities for remote, and self-directed learning. Second, there is a spiraling of contents tailored for each student. This allows for mastery of the competencies and facilitates learning from simple to complex. Third, students choose the delivery mode that they want; thus, flexible learning approach may be adopted. Fourth, students are exposed to project-based tasks to develop their collaborative and problem-solving skills which are beneficial in their future careers. Fifth, students are given more opportunities for participatory learning through field experiences such as practicums, mentoring, and cooperative projects. Sixth, students are given opportunities to apply their theoretical knowledge to practice and use their reasoning skills to make sound interpretations and judgments. Seventh, teachers use authentic assessments in evaluating learners' performance. Eighth, students will be involved in the conceptualization and enhancement of the curriculum. Lastly, students are encouraged to become responsible for their learning. These nine trends highlight the shift of the limelight of learning responsibilities from the teacher to the students.

Furthermore, Dunwill (2016) purports that the advancement of technologies provides limitless possibilities in education. Thus, it will keep on altering the teaching practices and the learning process in general. Other educational institutions from different countries around the world have also started to embrace these changes. In Malaysia, Hussin (2018) pointed out that tertiary education in the country supports a flexible seating arrangement that is more supportive of both individual and collaborative workspaces. Alternative assessments are used to accommodate multiple learning styles, and Massive Open Online Courses (MOOCs) and other online learning platforms are already utilized. Similarly, data from U.S. Government (2017) showed that the country had been leading foundational researches in artificial intelligence (AI) cascading it down to research initiatives on strategic computing, big data, and brain research. Likewise, Canada supports Learning in the Digital Age, highlighting Digital and Media Literacy, which gives students the adaptive capabilities to be an active part in the global digital society (Brown-Martin, 2017). Penprase (2018, p. 211) cited that the "the proliferation of new educational institutions and new curricula after the first two industrial revolutions enabled the technical and managerial capacity to implement the massive expansion of the economy and manufacturing that arose in the twentieth century". The most familiar exponential technology is the exponential increase in computer power and decreasing cost in storage, which obeys a geometric relation commonly known as Moore's Law. 
Besides, the following initiatives and movements of various countries have also been recorded to address Education 4.0. The ASEAN Work Plan on Education 2016-2020 incorporated pertinent priorities, such as the utilization of ICT through the expansion of ASEAN Cyber University (ACU). Meanwhile, Singapore has also been very consistent with their remarkable results in the Program for International Student Assessment (PISA). The country has put premium in its education system evident in its integration into its overarching national strategy (Brown-Martin, 2017). On the other hand, Myanmar has undertaken ways to restructure their higher education institutions through these four phases"foundation building, interdisciplinary institutions, mainstreaming 21 st-century skills and multidisciplinary collaborations" (Mustafa, 2018, p. 31). In Malaysia, Higher Education Framework 4.0 (MyHE 4.0) was established for the universities to change their curriculum and delivery to ensure that universities will produce well-rounded graduates who can easily adjust and fill in jobs that are yet to exist.

Education 1.0 was teaching through lectures and memorization, Education 2.0 introduced the usage of technology and the internet, Education 3.0 was on knowledge production; while an innovative-production is needed for Education 4.0 (Siltharm, 2017). With the demands of Education 4.0, are higher education institutions in the Philippines ready? The study of Pangandaman et al. (2019) described the current state of Philippine higher education in addressing Education 4.0. They have concluded that educational facilities, technological advancements, and research are important features of a tertiary institution in becoming an education 4.0 ready.

The study of Halili (2019) on teaching and learning in the fourth industrial revolution underpinned the following four components to meet the challenges of Education 4.0. First, redesigning of the learning spaces utilizing collaborative tables and smartboard. Second, employing varied education processes such as heutagogy, peeragogy, and cybergogy. Third, integrating an interdisciplinary and a flexible curriculum wherein schools can employ innovations without being constricted to traditional curriculum practices. Lastly, employing technological advancements such as robotics, artificial intelligence, virtual and augmented reality, cloud computing, big data, 3D printing, and so forth to aid teaching and learning. Wallner and Wagner (2016) also purports the crucial drivers of complexity in teaching and research undertakings in Education 4.0. These are interculturalism and multiculturalism; mobile devices and media platforms; selfpaced and individualized study plans; a variety of available resources and technologies; innovation and production of new knowledge; and, creation of "enabling spaces" for students.

It is the intent of this study to determine the readiness of teacher education institutions in the Philippines for Education 4.0 in the areas of faculty, teaching and learning, infrastructure, and research as perceived by the administrators and faculty members of teacher education institutions in the Philippines. The findings of the study could be used as a basis for policy formulation or strategic actions to enable teacher education institutions to meet the requirements of Education 4.0. 


\section{Methodology}

This study employed descriptive quantitative research design utilizing survey questionnaire as the main data gathering tool. The questionnaire (see Appendix 1) is composed of four parameters under study: faculty, teaching and learning, infrastructure, and research. The Likert scale is used as this provides an effective way for the researchers to draw out relevant responses from the participants. Each parameter has eight indicators wherein participants will choose from a multiplechoice option - strongly agree, agree, disagree, strongly disagree. Before the conduct of the study, the researchers tried out the questionnaire to the faculty members and administrators of a teacher education institution to establish reliability.

The participants of this study are four hundred fifty (450) faculty members and administrators from different teacher education institutions in the country. The administrators, in the context of this study, are those teachers who also hold administrative positions in their school like the vice-presidents, deans, and department chairs.

Ethical considerations highlighted in this study include (a) informed consent, (b) beneficence, (c) confidentiality and anonymity, and (d) respect for privacy, and the right to withdraw from the study anytime. Before the participants answered the survey questionnaire, the researchers gave the rationale of such research undertaking. Informed consent was sought and the participants may or may not answer the questionnaire given. There were also informal interviews conducted to help the researches make sense of the responses in the questionnaire. The participants will not be linked to the data. Their identify and affiliation will also be kept confidential.

After the data were collected and summed up, results were tallied, collated, and tabulated for analysis and interpretation.

\section{Results and Discussion}

The study determined the readiness of teacher education institutions in the Philippines as perceived by administrators and faculty members in the areas of faculty readiness, teaching and learning practices, infrastructure requirements, and research programs and initiatives.

Table 1: Faculty Readiness

\begin{tabular}{lcc}
\hline As a faculty, I am ready for Education 4.0 because I ... & $\begin{array}{c}\text { Weighted } \\
\text { Mean }\end{array}$ & Description \\
\hline $\begin{array}{l}\text { 1. am technologically literate } \\
\text { 2. am skillful in the use of learning management } \\
\text { system, google classroom, and online class modality }\end{array}$ & 2.89 & Agree \\
$\begin{array}{l}\text { 3. accept the vital role of technology in the 21 st century } \\
\text { and beyond }\end{array}$ & 3.41 & $\begin{array}{c}\text { Disagree } \\
\text { Strongly } \\
\text { Agree }\end{array}$ \\
$\begin{array}{l}\text { 4. integrate digital technology in teaching and } \\
\text { learning }\end{array}$ & 2.6 & $\begin{array}{c}\text { Agree } \\
\text { 5. attend seminars and conferences to enhance my } \\
\text { technological and pedagogical skills }\end{array}$ \\
\hline
\end{tabular}


6. experiment new approaches using technology

7. lead in the development of innovative materials

8. collaborate and build partnerships from other institutions

TOTALITY
2.63

2.54

2.81

2.86
Agree

Agree

Agree

Agree

Educators play a significant role in any decision making and policy reform as they are the navigators and the direct implementers of these curricular changes. They need to be at the forefront of these innovations with their commitment to ensuring an all-out effort for quality education. With Education 4.0, are the faculty members in teacher education institutions ready to be Teacher 4.0?

Table 1 shows the faculty members' perceived readiness for Education 4.0 as mostly determined by their skills in selecting, developing, designing, and integrating relevant digital resources for teaching and learning. In totality, with a mean average of 2.86, the faculty members agreed that they are ready for Education 4.0. They agreed in most statements that characterized Teacher 4.0 like being technologically literate, integrating digital tools in their classroom practices, experiment and lead in the development of innovative tools, and establish partnerships from other institutions. The result implies that faculty members in teacher education institutions do not only acknowledge the fact that they need to take advantage of the digital tools available but also to take the lead in adopting and conceptualizing new methods, a new concept of teaching, to keep abreast with the fast-paced technological advancements. Moreover, teacher education institutions should be consistent in their role in fostering innovation and increasing higher-order skills among their students for improved quality of life. It is for this reason that continuous training is afforded to faculty members. The result shows that the participants strongly agreed that capacity buildings through seminars and conferences related to technological literacy have helped them enhance their digital skills. Most universities give importance to capacity-building programs according to the individual development plan of their faculty members and their strategic directions. A skilled teacher is a vital resource in any educational institution. Given this, a teacher's professional training and development is a necessary component that supports innovative and valuable teaching.

However, despite the participants' claim that they are technologically literate, most of them, although they are good at manipulating digital tools, have little exposure to learning management systems and other online class modality. Learning Management Systems or LMS provides both teachers and students informational content and educational resources online. LMS is a way to ease the work of educators by giving them a chance to take advantage of numerous eLearning opportunities and platforms which are flexible. Options include google classroom, Moodle, Schoology, neo-LMS, etc. which offers teachers an easier and faster way of tracking student records and in presenting course materials and documents. Teachers can use these tools for online, blended, or flipped classrooms. The result suggests that faculty members in teacher education have not extensively used online or blended learning in their classes. Most universities in the country still give premium to face to face interactions and not so much on 
blended learning, online and, or distance learning. Most of them have not offered MOOCs as well.

Massive open online courses (MOOCs) have been gaining popularity in today's educational institutions, where physical, cultural, and socioeconomic boundaries no longer stop students from continuing and furthering their studies. Xing and Marwala (2017), in their framework for Teaching in IR 4.0, highlighted blended learning and massive open online courses. In the Philippines, the University of the Philippines Open University (UPOU) has started offering MOOCs since 2013. In some universities, face-to-face courses are incorporated with some online components, like in flipped classrooms, in which traditional in-class activities are complemented, rather than replaced, with online undertakings. However, MOOCs are getting more popular as this resolves student concern on accessibility and time. These are self-instructional and self-paced courses enabling students to have control over when and where to learn using the devices of their choice.

In view of the learning opportunities and pedagogical advantages of online learning, school administrators need to give importance to teacher training on developing online materials, navigating in various online platforms, and looking for innovative ways of using such platforms to improve learning outcomes.

Table 2. Teaching and Learning Practices

\begin{tabular}{|c|c|c|}
\hline My classes are Education 4.0 because I.. & $\begin{array}{l}\text { Weighted } \\
\text { Mean }\end{array}$ & Description \\
\hline \multicolumn{3}{|l|}{$\begin{array}{l}\text { 1. use the following strategies in the delivery of } \\
\text { instruction: }\end{array}$} \\
\hline a. individualized teaching & 2.70 & Agree \\
\hline b. gamification and simulation & 2.72 & Agree \\
\hline c. problem and inquiry-based teaching and learning & 2.67 & Agree \\
\hline d. augmented and virtual reality & 2.00 & Disagree \\
\hline $\begin{array}{l}\text { 2. boost students' creativity through digital enablers like } \\
\text { 3D printing and robotics }\end{array}$ & 1.93 & Disagree \\
\hline $\begin{array}{l}\text { 3. use technology-based assessment tools (ex. Kahoot, } \\
\text { Quizlet, etc.) }\end{array}$ & 2.79 & Agree \\
\hline 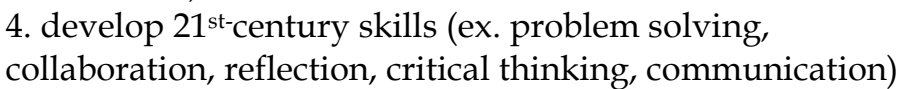 & 2.96 & Agree \\
\hline $\begin{array}{l}\text { 5. teach digital citizenship (technology ethics, social, } \\
\text { ethical and legal responsibilities in the utilization of } \\
\text { technological tools and resources, etc.) }\end{array}$ & 2.77 & Agree \\
\hline 6. use individualized modular instructional materials & 2.69 & Agree \\
\hline $\begin{array}{l}\text { 7. expose students to more participatory learning through } \\
\text { field experiences }\end{array}$ & 3.08 & Agree \\
\hline $\begin{array}{l}\text { 8. accommodate multiple learning styles through flexible } \\
\text { assignments }\end{array}$ & 3.08 & Agree \\
\hline TOTALITY & 2.67 & Agree \\
\hline
\end{tabular}

The respondents claim that they are technologically literate and are capable of navigating through different digital tools as reflected in their teaching-learning practices. Table 2 reveals that the faculty members in teacher education institutions agreed that their teaching and learning practices are Education 4.0. 
They claimed that they use various teaching strategies like individualized teaching, gamification and simulation, and problem and inquiry-based teaching and learning. Moreover, they also utilize personalized modular instructional materials, expose students to hands-on learning through field experiences, and provide flexible assignments accommodating students' different learning styles.

However, it was also revealed that they have not fully utilized the use of digital enablers like 3D printing, robotics, and augmented and virtual reality. Teaching and the whole learning process in the context of Education 4.0 not only challenges universities to teach enduring understandings and relevant technologies but also to employ new ways to transfer learning among students quickly and simply. The whole community of learning needs to keep abreast of the current trends and employ teaching models to respond effectively in this new learning environment (Prieto, et al, 2015). With these rapid and spontaneous economic and social changes, teacher education institutions should see that they are preparing their graduates for a future that has never been this uncertain. What jobs will still be available years from now? What skills will still be relevant to them? What knowledge is considered the most essential considering the limitless possibilities and limitless access to data and information? What problems will arise years from now, and will they be ready to deal with these problems? With this so many uncertainties thus, teachers should not only be able to put up with the needs of the digital communities but also to see to it to teach students critical life skills (creativity, critical thinking, problem-solving, adaptability, etc). Technological change may have the effect of undermining rather than empowering workers and their children (Berger \& Engzell, 2020) especially in the teaching and learning practices. They added that the interplay between automation on one hand and the distribution of bargaining power and access to educational opportunities on the other should be studied.

Moreover, as reflected in the results, educational institutions need to invest in new technology like 3D printing technologies and augmented reality. These help students develop the $4 \mathrm{C}^{\prime}$ s of 21st-century learning: creativity, critical thinking, communication, and collaboration. To add, augmented Reality (AR) and Virtual Reality (VR) significantly "shifts the location and timing of education and training" (Lee, 2012, p. 1). In virtual reality, one is brought to a virtual space or in an artificial environment, while augmented reality (AR) allows students to view and interact with computer-generated images in the real world. This brings teaching and learning to a different level and shows a lot of promise. Moreover, 3D printers provide real-world application and knowledge and should also be standard tools in higher education - and not just in STEM subjects. These immersive tools promote students' problem-solving and creativity skills as they become actively involved in the conception, design, and execution of their projects.

However, the choice and use of any learning innovation depend on the availability of these technologies and infrastructure. Thus, universities should also make these tools and infrastructure available and accessible for both teachers and students. Moreover, the availability of these tools is complemented by 
teachers' skills in using them. Some inhibitors and reasons for teachers not using these tools may include their lack of experience in ICT and the absence of support and mentoring given to them. Teacher capability programs should consist of training them with the skills in designing, creating, and applying these assistive and immersive tools to address the new and emerging paradigms of learning. Corollary to this, universities need to maximize the power of these immersive technologies not only for effective teaching and learning but also for relevant and responsive research and innovation.

Table 3. Infrastructure Requirements

\begin{tabular}{lcc}
\hline $\begin{array}{l}\text { The institution where I'm currently employed is ready for } \\
\text { Education } 4.0 \text { because it... }\end{array}$ & $\begin{array}{c}\text { Weighted } \\
\text { Mean }\end{array}$ & Description \\
\hline $\begin{array}{l}\text { 1. has an office that takes charge of the ICT needs of the } \\
\text { university/college }\end{array}$ & 2.93 & Agree \\
$\begin{array}{l}\text { 2. has a stable internet connection which is accessible both } \\
\text { for teachers and students }\end{array}$ & 2.39 & Disagree \\
$\begin{array}{l}\text { 3. has available teaching and learning spaces that provide } \\
\text { greater opportunity for collaboration }\end{array}$ & 2.49 & Disagree \\
$\begin{array}{l}\text { 4. has digital infrastructure which provides open access to } \\
\text { the repository of information and scientific data. }\end{array}$ & 1.85 & Disagree \\
$\begin{array}{l}\text { 5. has technology that provides access to blogs, vlogs, } \\
\text { wikis, google classroom, Edmodo, and other related sites } \\
\text { and reference databases (e.g., Google Scholar, Ebsco Host, }\end{array}$ & 2.47 & Disagree \\
$\begin{array}{l}\text { LISA, etc.) } \\
\text { 6. has a computer laboratory with internet connection in } \\
\text { which students can watch educational videos and } \\
\text { collaborate with other students and other universities }\end{array}$ & 2.51 & Agree \\
7. has remote and virtual laboratories & 2.17 & Disagree \\
\begin{tabular}{l} 
TOTALITY \\
\hline
\end{tabular} & 2.40 & Disagree \\
\hline
\end{tabular}

The availability and accessibility of high-quality and updated infrastructure among teacher education institutions is a crucial foundation of conducive learning environments. It facilitates instructional quality, thus improve student outcomes. Educational institutions can respond to Industry 4.0 by harnessing the potential of digital infrastructure, open educational resources (OER), networked education, and lifelong learning.

Table 3 shows that the faculty members and administrators perceived that teacher education institutions are not ready in terms of infrastructure requirements. Although there is an office that takes care of the ICT needs of their universities, and the availability of computer laboratories, they still have to establish reliable internet connectivity and the accessibility of remote and digital infrastructure. Moreover, there is also a concern about the availability of virtual laboratories and state-of-the-art libraries and teaching-learning spaces that allow for flexibility to be Education 4.0 ready.

Most universities have already embraced several changes in the delivery of instruction, which includes the use of digital tools and digital applications. The most common cry among educators is the slow internet connection or limited to 
no access from those who live in the provinces. This situation can be considered an educational setback and may significantly impact teachers' performance in delivering instruction as well as student's academic success and career opportunities. Also, virtual laboratories help students be exposed to and perform on real live online trials. Obtaining practical skills through experiments provides students a more profound sense of the concepts taught to them. Virtual laboratory activities can save money, time, and effort but still safe and interactive, thus allowing for more student involvement. Schools also need to envision the future of academic libraries through the availability of state-of-the-art libraries. The scenario of so many piled hard-bound books may no longer be the trend, but a wide array of e-books that are all a click away.

Acatech (2014), as cited in Morrar et al. (2017, p. 14) purported that "Industry 4.0 as the Internet of Things (IoT), data and services that will change future production, logistics, and work processes". This means that everything is connected to the internet be it device, processes, people, and even animals through embedded systems, and wireless connection. Most of the universities and colleges do not have a reliable internet connection and a stable learning management system (LMS) for online learning and distance education. Faculty members are willing to innovate, but they do not have the digital infrastructure, which provides unlimited access to the repository of information and scientific data. There are also limited resources for further commercialization of research outputs and innovations.

Education 4.0 is highly related to innovation. According to Morrar et al. (2017, p. 15), "industry 4.0 represents a shift toward an innovation-based economy with knowledge, data, and the IoT as central concepts". Most colleges and universities in the Philippines do not have remote and virtual laboratories essential in the fourth industrial revolution. Some universities have virtual laboratories for electronics, manufacturing, and other areas but these are not enough for innovations.

Likewise, new technologies are emerging faster, being adopted more quickly and delivering greater impact than ever before. Fourth Industrial Revolution technologies will create new ways for citizens to connect, to trade with each other, and to access services that are currently not available (World Economic Forum Asian Development Bank, 2017). Many students and teachers have hopeful expectations for the future of the Fourth Industrial Revolution especially in the delivery of instruction and the outcomes of education. If people focus only on leveraging the information that they have and do not pay sufficient attention to building basic infrastructure, then it will be a failure to make the Fourth Industrial Revolution a reality (Yoon, 2017).

An institution of higher learning must have a reliable internet connection, which is accessible both for teachers and students. "Though broadband users can get high-quality video feedback, 56kbps-modem users cannot get good video quality. Multicast video is another issue for Internet/Intranet video broadcasting. Multicast is a one-to-many connection in which multiple clients receive the same 
stream from a server", Sheng, et.al. (2000, p. 53). Educators are excited about robotics, IoT, digitalization, automatization, and teleconferencing. They are also willing to help their institution attain its objectives in Education 4.0. Some of the respondents said that they are willing to innovate for their learners if there is considerable support for training and infrastructure budget to uplift their ICT resources. This statement implies that educators are proactive in Industry 4.0.

Table 4. Research Programs and Initiatives

\begin{tabular}{lcc}
\hline $\begin{array}{l}\text { The institution where I'm currently employed is } \\
\text { Education 4.0 ready because... }\end{array}$ & $\begin{array}{c}\text { Weighted } \\
\text { Mean }\end{array}$ & Description \\
\hline $\begin{array}{l}\text { 1. research undertakings are geared towards } \\
\text { innovations }\end{array}$ & 2.11 & Disagree \\
$\begin{array}{l}\text { 2. there is an allocated budget for research activities } \\
\begin{array}{l}\text { 3. research outputs are used for policy } \\
\text { recommendations }\end{array}\end{array}$ & 2.55 & Agree \\
$\begin{array}{l}\text { 4. some research outputs generate new models for } \\
\text { teaching and assessment }\end{array}$ & 2.66 & Agree \\
$\begin{array}{l}\text { 5. there is multidisciplinary collaboration in the } \\
\text { conduct of research }\end{array}$ & 2.01 & Disagree \\
$\begin{array}{l}\text { 6. there is a local partnership in research projects } \\
\text { 7. international partnership is evident in the conduct of } \\
\text { research activities }\end{array}$ & 3.03 & Agree \\
$\begin{array}{l}\text { 8. there is a program for research mentoring and } \\
\text { coaching } \\
\text { TOTALITY }\end{array}$ & 2.15 & Disagree \\
\hline
\end{tabular}

The country expects higher education institutions to lead in creating breakthroughs in education through research. Research production, dissemination, and utilization is even a critical predictor in university rankings. Moreover, faculty research production is also an essential element for their success as this is one basis for hiring or promotion and institutional reputation. Giving premium to research and innovation is also a reliable indicator that teacher education institutions respond to the needs of Industry 4.0 as they continuously explore and enable new possibilities where humans and technology are aligned.

However, Table 4 reveals that the respondents disagreed on most of the statements, which means that the teacher education institutions are not ready for research programs and initiatives for Education 4.0. Although the respondents agreed that there is research mentoring and coaching, and some research outputs are used for policy recommendations, most of them disagreed that research undertakings are geared towards innovations and research outputs that generate new models for teaching and assessment.

Education resources at this time are more focused on pedagogical and content knowledge and very limited to technological advancement and research undertakings and innovations. There is a need for educators to collaborate with both local and international researchers and take advantage of the limitless possibilities of communication channels. Institutions should also make international collaboration part of a university's culture. For some time, these partnerships have contributed endlessly to academic and scientific progress. A 
social network, according to Newman (2001), is a "collection of people, each of whom is acquainted with some subset of the others". These people from different places or countries are glued together, for example as researchers, because they have the same expertise or interest. The goal is to expand the network creating more collaboration and communication. As the total number of connections and research collaborators increases, the best practices will be shared and utilized. These collaborations afford universities research opportunities and cultural awareness. "The workplace of the future will not necessarily be a fixed geographical location but may be geographically distributed and functionally divided" (Johannessen, 2018, p. 27). Thus, it is now easier to collaborate with researchers in the world. They will also pave the way for benchmarking best practices in teaching, and curriculum development among institutions.

Johannessen (2018) mentions that the fourth industrial revolution will shape the workplaces of the future, which will be entirely different from the workplaces created by the first, second, and third industrial revolutions especially in terms of research and innovations.

Hoeschl, Bueno and Hoeschl (2017) specified that ethics is very important in conducting research. In their study, they identified and evaluated very important issues and concerns that need to be considered to improve the connections between technology and society. There are also many things to consider especially in the maintenance of the equipment. Meckawey (2019) analyzed the maintenance concept that will be applied in maintenance process due to the $4^{\text {th }}$ industrial revolution tools, which should also be implemented.

Bland et al. (2005) concluded that, "when individual faculty's research productivity is the goal, nothing substitutes for these four factors: recruiting faculty with a passion for research; providing them with formal mentoring programs; facilitating their networks; and providing time for them to do research". To answer the call of Education 4.0, high levels of research productivity as well as developing and maintaining an influential culture of research should be evident. Thus, institutions desiring to create a culture of research must give high regard in the acquisition of relevant resources for faculty development.

\section{Conclusion}

This study tried to find out if teacher education institutions in the Philippines are ready for Education 4.0. The researchers determined the "readiness for Education 4.0" through the different identified areas based on an extensive review of related literature and studies. Various studies pointed out these four areas should be emphasized by teacher education institutions in responding to Education 4.0: faculty, teaching and learning, infrastructure, and research. Since there is now a significant shift in the future of learning, where the use of digital tools and digital platforms is no longer an option but a way of life, it becomes a necessity for educational institutions to prepare, embrace, and act on these changes. The symbiotic relationship between education institutions and society, in general, has transformed into a whole new level, and this calls for a dynamic transformation of both. Moreover, this study confirms the importance of technological and 
pedagogical innovations, which can be achieved only if the Industry 4.0 is recognized simply in the form of technical, infrastructure, pedagogical, and research innovation. Education 4.0 sheds light on the bright side of its potential such as technological innovations, IT infrastructure, teaching and learning (pedagogical), and research engagement.

With the transition to Industry 4.0, school administrators should emphasize the urgency to redesign the education system. They should also work closely with people from the industry sectors in reskilling and upscaling their graduates. Further, policymakers should think of the global impact of Industry 4.0 on the current education system and provide for appropriate human resource training and development, support for infrastructure acquisition, and enough budget for research and innovation.

Moreover, with the sudden shift of most universities in the Philippines (because of the pandemic), from face-to-face and blended teaching, to online synchronous and online asynchronous teaching, this provides opportunities for future researches that would further elaborate the findings of this study. This study could be extended and expounded in terms of how higher education institutions respond now to the immediate need of upgrading their IT infrastructure and furthering research initiatives. Further work is also suggested to examine the practices of higher education institutions in responding to the call of Education 4.0 especially during this time of pandemic.

\section{References}

Berger, T., \& Engzell, P. (2020). Intergenerational Mobility in the Fourth Industrial Revolution. https://doi.org/10.31235/osf.io/zcax3

Bland, C. J., Center, B. A., Finstad, D. A., Risbey, K. R., \& Staples, J. G. (2015). A theoretical, practical, predictive model of faculty and department research productivity. Academic Medicine, 80(3), 225-237. https://doi.org/10.1097/00001888-20050300000006

Brown-Martin, G. (2017). Education and the fourth industrial revolution. Retrieved from https://medium.com/regenerative-global/education-and-the-fourth-industrialrevolution-cd6bcd7256a3

Dadios, E. P., Culaba, A. B., Albert, J. R. G., Paqueo, V. B., Orbeta, A. C., Serafica, R. B., Bandala, A. A., \& Bairan, J. C. A. C. (2018). Preparing the Philippines for the Fourth Industrial Revolution: A Scoping Study. Philippines Institute for Development Studies. Discussion Paper Series No. 2018-11.

Dunwill, E. (2016). 4 changes that will shape the classroom of the future: Making education fully technological. Retrieved from https://elearningindustry.com/4-changeswill-shape-classroom-of-the-future-making-education-fully-technological

Fisk, P. (2017). Education 4.0 ... the future of learning will be dramatically different, in school and throughout life. Retrieved from https://www.thegeniusworks.com/2017/01/future-education-youngeveryone-taught-together/

Halili, S. (2019). Technological advancements in education 4.0. The Online Journal of Distance Education and e-Learning, 7(1), 63-69. Retrieved from http://www.tojdel.net/journals/tojdel/articles/v07i01/v07i01-08.pdf

Haron, H. (2018). Education in the era of IR 4.0. Keynote Speech at the 2018 International Conference on Information Management and Technology (ICIMTech 2018), 3 - 5 
September 2018. Jakarta, Indonesia. Retrieved from http:/ / umpir.ump.edu.my/id/eprint/22486/1/Education\%20in\%20the\%20Era \%20of\%204.0.pdf

Hoeschl, M. B., Bueno, T. C., \& Hoeschl, H. C. (2017, November). Fourth industrial revolution and the future of engineering: could robots replace human jobs? How ethical recommendations can help engineers rule on artificial intelligence. In 2017 7th World Engineering Education Forum (WEEF)(pp. 21-26). IEEE. https://doi.org/10.1109/weef.2017.8466973

Hussin, A. A. (2018). Education 4.0 made simple: Ideas for teaching. International Journal $\begin{array}{llll}\text { of Education } \text { and Literacy } & \text { Studies, 6(3), }\end{array}$ https://doi.org/10.7575/aiac.ijels.v.6n.3p.92

Johannessen, J. A. (2018). Automation, innovation and economic crisis: Surviving the fourth industrial revolution. Routledge. https:// doi.org/10.4324/9781351039864

Lee, K. (2012). Augmented reality in education and training. TechTrends, 56(2),13-21. https://doi.org/10.1007/s11528-012-0559-3

Meckawey, M. (2019, February). The Maintenance's Strategy \& the 4 th Industrial Revolution. In 2019 International Conference on Fourth Industrial Revolution (ICFIR) (pp. 1-8). IEEE. https:// doi.org/10.1109/icfir.2019.8894795

Morrar, R., Arman, H., \& Mousa, S. (2017). The fourth industrial revolution (Industry 4.0): A social innovation perspective. Technology Innovation Management Review, 7(11), 12-20.

Mustafa, Z. (2018, May 16). Asean experience for IR 4.0. New Straits Times, pp. 1-6. Retrieved from https://www.nst.com.my/education/2018/05/369959/aseanexperience-ir-40

Newman, M. E. (2001). The structure of scientific collaboration networks. Proceedings of the national academy of sciences, 98(2), 404-409.

Overseas Research Report (2015). Current status on science and technology in ASEAN countries. Center for Research and Development Strategy, Japan Science and Technology Agency. Retrieved fromhttps://www.jst.go.jp/crds/pdf/en/CRDSFY2014-

OR- 02_EN.pdf

Pangandaman, H. K., Ali, N. D., Lambayong, J. H. C., \& Ergas, M. L. G. (2019). Philippine higher education vis-à-vis education 4.0: A scoping review. International Journal of Advanced Research and Publications, 3(3), 65-69. Retrieved from http://www.ijarp.org/published-research-papers/mar2019/Philippine-HigherEducation-Vis-vis-Education-40-A-Scoping-Review.pdf

Penprase, B. E. (2018). The Fourth Industrial Revolution and Higher Education. In N. Gleason (ed.), Higher Education in the Era of the Fourth Industrial Revolution. Palgrave Macmillan Singapore. https://doi.org/10.1007/978-981-13-0194-0_9

Puncreobutr, V. (2016). Education 4.0: New challenge of learning. St. Theresa Journal of Humanities and Social Sciences, 2(2). Retrieved from http://www.stic.ac.th/ojs/index.php/sjhs/article/view/Position\%20Paper3

Shahroom, A. A., \& Hussin, N. (2018). Industrial revolution 4.0 and education. International Journal of Academic Research in Business and Social Sciences, 8(9), 314319.

Sheng, W. U., Choo-Min, L. I. M., \& Khiang-Wee, L. I. M. (2000). An integrated Internetbased control laboratory. IFAC Proceedings Volumes, 33(31), 49-53.

Sikdar, M., \& Balwaria,)R. (2013). Role of teachers amidst educational reform - passive bystanders or active participants? International Journal of Scientific and Research Publications, 3(10). Retrieved from http://www.ijsrp.org/research-paper1013/ijsrp-p2224.pdf 
Schwab, K. (2016). The Fourth Industrial Revolution. World Economic Forum

Leapfrogging to education 4.0: Student at the core (2017). FICCI Higher Education Report. Retrieved from https://www.parthenon.ey.com/po/en/perspectives/leapfrogging-toeducation-4-0-student-at-the-core

TESDA (2016). Technological changes is coming: The fourth industrial revolution. Labor market intelligence report.

U.S. Government. (2017). Preparing for the future of artificial intelligence. Ai \& Society, 32(2), 285-287. https:// doi.org/10.1007/s00146-016-0685-0

Wallner, T., \& Wagner, G. (2016). Academic education 4.0. In the Proceedings of the END International Conference on Education and New Developments, 12-14 June. Ljubljana, Slovenia. Retrieved from https://www.researchgate.net/publication/304115292_ACADEMIC_EDUCATI ON_40

Welsh, B, (2018, April 18). Education 4.0 - How we will learn in the fourth industrial revolution. Retrieved from https://medium.com/@brianna_91610/education-4-0how-we-will-learn-in-the-fourth-industrial-revolution-e17206b73016

World Economic Forum Asian Development Bank (ADB). (2017). ASEAN 4.0: what does the Fourth Industrial Revolution mean for regional economic integration? World Economic Forum, Geneva, Switzerland. http:// dx.doi.org/10.22617/TCS1791262

Xing, B., \& Marwala, T. (2017). Implications of the fourth industrial age on higher education. Computers and Society, Cornell University. http://arxiv.org/abs/1703.09643

Yoon, D. (2017). What we need to prepare for the fourth industrial revolution. Healthcare informatics research, 23(2), 75-76. https://doi.org/10.4258/hir.2017.23.2.75 


\section{Appendix 1}

Teacher Education Institutions in the Philippines Towards Education 4.0

The purpose of this survey is to determine the readiness of Teacher Education Institutions in the Philippines with regard to Education 4.0. This will only take approximately 5-10 minutes to complete. Your answers will be greatly appreciated. Thank you very much.

Name of Institution (optional)

Category: SUC

Accreditation level:

Private (Sectarian)

CHED award: $\mathrm{COE}$
LUC Private (Non-Sectarian)

Position in the University/College:

Accrediting body: Not Applicable

Part I. Directions: Please check the appropriate column that best applies to you and to your Teacher Education Institution or College.

\begin{tabular}{|l|l|l|l|l|}
\hline $\begin{array}{l}\text { A. Faculty Readiness } \\
\text { As a faculty in the institution where I'm } \\
\text { employed, I... }\end{array}$ & $\begin{array}{l}\text { Strongly } \\
\text { Agree }\end{array}$ & Agree & Disagree & $\begin{array}{l}\text { Strongly } \\
\text { Disagree }\end{array}$ \\
\hline $\begin{array}{l}\text { 1. am technologically literate } \\
\text { 2. am skillful in the use of learning } \\
\text { management system, google } \\
\text { classroom, and online class modality }\end{array}$ & & & & \\
\hline $\begin{array}{l}\text { 3. accept the important role of } \\
\text { technology in the 21 st century and } \\
\text { beyond }\end{array}$ & & & & \\
\hline $\begin{array}{l}\text { 4. integrate digital technology in } \\
\text { teaching and learning }\end{array}$ & & & & \\
\hline $\begin{array}{l}\text { 5. attend seminars and conferences to } \\
\text { enhance my technological and } \\
\text { pedagogical skills }\end{array}$ & & & & \\
\hline $\begin{array}{l}\text { 6. experiment new approaches using } \\
\text { technology }\end{array}$ & & & & \\
\hline $\begin{array}{l}\text { 7. lead in the development of } \\
\text { innovative materials }\end{array}$ & & & & \\
\hline $\begin{array}{l}\text { 8. collaborate and build partnerships } \\
\text { from other institutions }\end{array}$ & & & & \\
\hline $\begin{array}{l}\text { Others: } \\
\text { D. Teaching and Learning Practices } \\
\text { My classes are Education 4.0 because I ... }\end{array}$ & & & & \\
\hline $\begin{array}{l}\text { 1. use the following strategies in the delivery } \\
\text { of instruction: }\end{array}$ & & & & \\
\hline a. individualized teaching & & & \\
\hline b. gamification and simulation & & & \\
\hline $\begin{array}{c}\text { c. problem and inquiry-based } \\
\text { teaching and learning }\end{array}$ & & & & \\
\hline d. augmented and virtual reality & & & \\
\hline
\end{tabular}




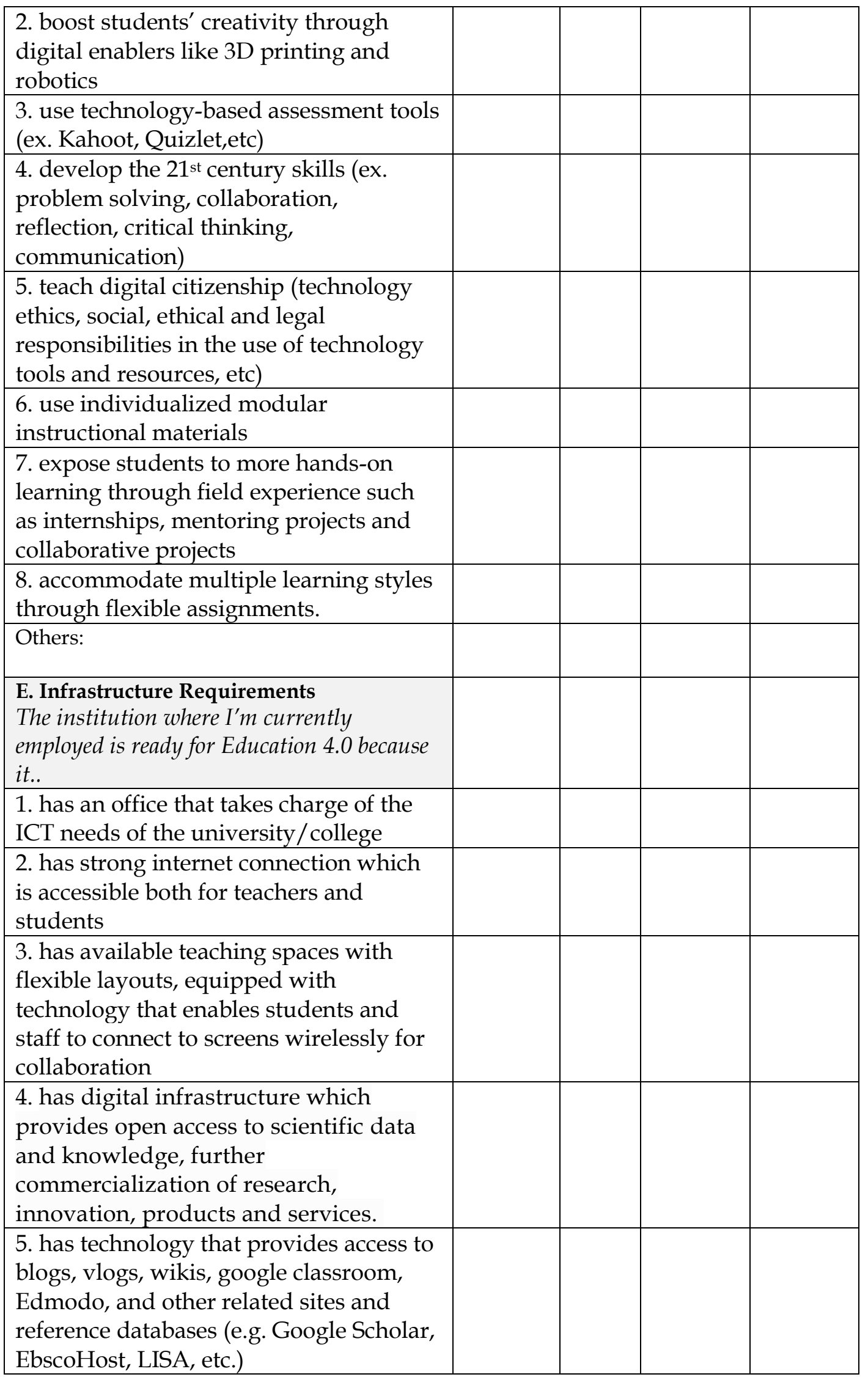




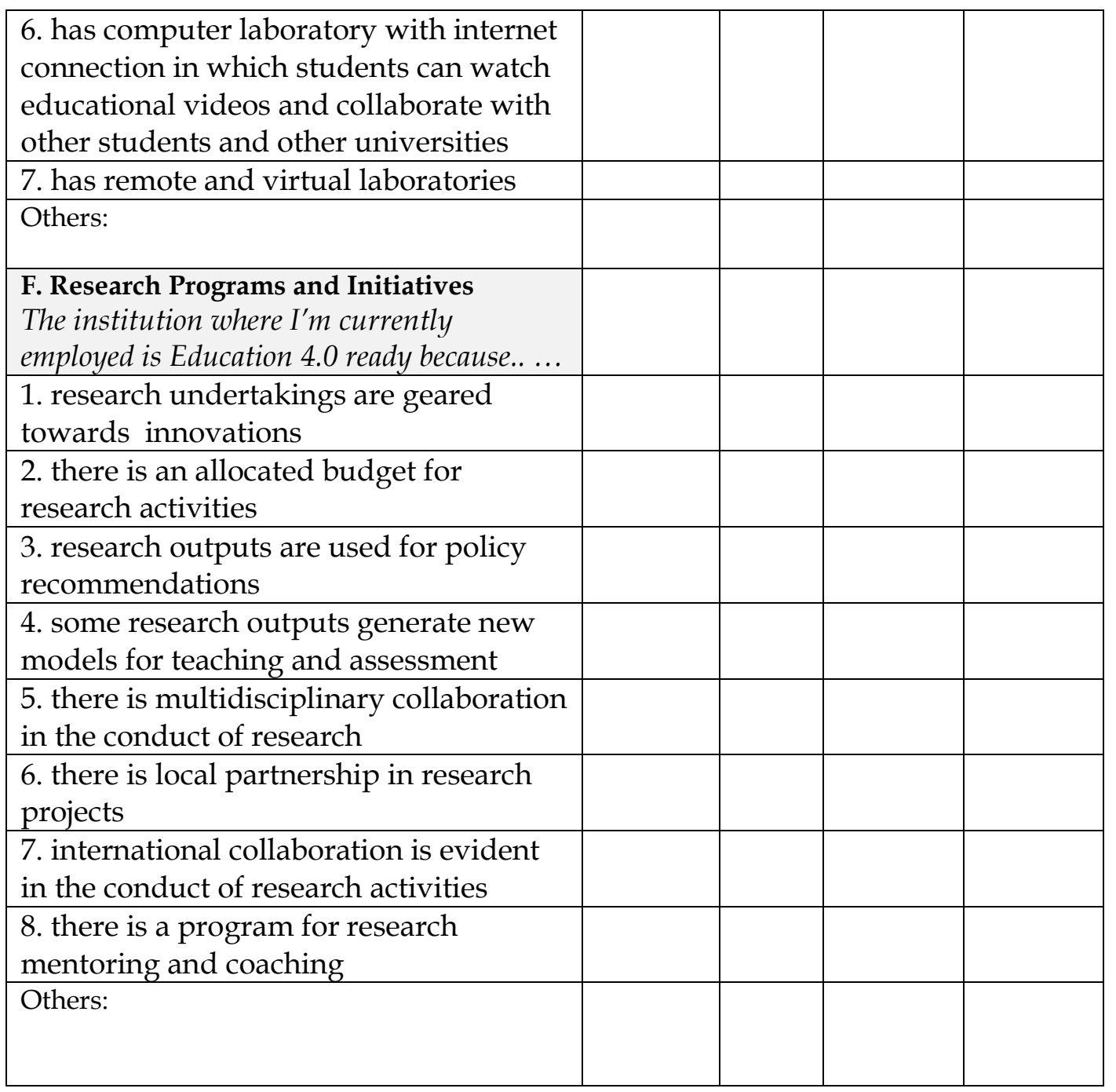

